\title{
Impact of climate change on photochemical air pollution in Southern California
}

\author{
D. E. Millstein and R. A. Harley \\ Department of Civil and Environmental Engineering University of California, Berkeley, CA 94720-1710, USA
}

Received: 3 December 2008 - Published in Atmos. Chem. Phys. Discuss.: 16 January 2009

Revised: 25 May 2009 - Accepted: 25 May 2009 - Published: 10 June 2009

\begin{abstract}
The effects of future climate and emissionsrelated perturbations on ozone air quality in Southern California are considered, with an assumed increase to $2 \times$ preindustrial levels for global background levels of carbon dioxide. Effects of emission and climate-related forcings on air quality are superimposed on a summer 2005 high-ozone time period. Perturbations considered here include (a) effect of increased temperature on atmospheric reaction rates, (b) effect of increased temperature on biogenic emissions, (c) effect of increased water vapor concentrations, (d) effect of increased pollutant levels at the inflow (western) boundary, and (e) effect of population growth and technology change on emissions within Southern California. Various combinations of the above perturbations are also considered. The climaterelated perturbations $(\mathrm{a}-\mathrm{c})$ led to combined peak 1-h ozone increases of up to $11 \mathrm{ppb}$. The effect on ozone was greatly reduced when the temperature increase was applied mostly during nighttime hours rather than uniformly throughout the day. Increased pollutant levels at the inflow boundary also led to ozone increases up to $5 \mathrm{ppb}$. These climate and inflowrelated changes offset some of the anticipated benefits of emission controls within the air basin.
\end{abstract}

\section{Introduction}

Ozone air quality varies depending on meteorological conditions. A positive correlation between ozone levels and temperature is a well-known aspect of this relationship (Aw and Kleeman, 2003; Clark and Karl, 1982; Lin et al., 2001; Sillman and Samson, 1995). Air quality management plans may be affected if an increase in emission control requirements is

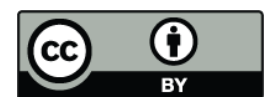

Correspondence to: R. A. Harley (harley@ce.berkeley.edu) needed to offset changes in climate that increase the severity and/or frequency of air pollution episodes.

Global analyses (Brasseur et al., 2006; Liao et al., 2006; Racherla and Adams, 2006; Stevenson et al., 2005; Unger et al., 2006) simulate future meteorology and air quality under different climate scenarios. With climate change these studies report ozone decreases in remote areas as destruction of ozone by water vapor increases with higher temperatures. The global models do not provide a consistent picture of the response of urban ozone levels to climate change.

Regional air quality models have been used to assess local air quality effects while incorporating global-scale changes. Racherla and Adams (2008) reported longer future ozone seasons and increases in summertime ozone levels in the eastern US using a "unified" model that allowed them to incorporate air quality impacts from climate change that occur outside their US study region. Jacobson (2008) used a global model with a nested regional US grid and found adverse effects on public health relating to climate change-induced air quality changes.

High-resolution air quality models are needed to study local effects on air quality, such as complex terrain, spatially resolved emissions, and fine-scale patterns of expected population growth. Studies such as Aw and Kleeman (2003), Steiner et al. (2006), and Kleeman (2008) refine the scale of interest to focus on air quality in urban areas. These studies incorporate predictions of future temperature changes and various feedbacks that may result. Effects on ozone varied strongly by location across each air basin, highlighting the importance of using a fine-scale grid for this type of analysis.

Other studies have examined the effects on air quality of changing the frequency of stagnation events. Mickley et al. (2004) report that changes in weather patterns (specifically the frequency of low-pressure systems passing through) lead to a lengthening of stagnation events across the eastern and mid-western US, creating longer and more

Published by Copernicus Publications on behalf of the European Geosciences Union. 
Table 1. Domain-wide emission totals (tons/day).

\begin{tabular}{lllllll}
\hline Source & \multicolumn{3}{l}{ Weekday Emissions (tons/day) } & \multicolumn{3}{l}{ Weekend Emissions (tons/day) } \\
& $\mathrm{NO}_{\mathrm{x}}$ & $\mathrm{NMOC}$ & $\mathrm{CO}$ & $\mathrm{NO}_{\mathrm{x}}$ & $\mathrm{NMOC}$ & $\mathrm{CO}$ \\
\hline Area/off-road mobile & 720 & 707 & 1498 & 612 & 738 & 2163 \\
On-road mobile & 775 & 353 & 3408 & 445 & 283 & 2806 \\
Point & 142 & 76 & 171 & 128 & 44 & 147 \\
Biogenic & & 713 & & & 719 & \\
\hline
\end{tabular}

severe ozone air pollution episodes. Similarly, Leung and Gustafson (2005) find evidence of increasing stagnation in Southern California during the fall, also leading to adverse effects on ozone air quality.

Duffy et al. (2006) discuss increases in observed surface temperatures for California over the last 50 years, pointing out that increases in temperature have been higher during the nighttime than daytime. They argue that global climate models do not represent accurately the seasonal or diurnal changes in the observed temperature record in California since 1950. Duffy et al. (2006) show that unmodeled forcings due to changes in land-use and irrigation affect trends in daily maximum temperatures. Bonfils and Lobell (2007) and Lobell and Bonfils (2008) show that increases in irrigation have had a cooling effect on daytime temperatures during summer. Ongoing work by Lebassi et al. (2009), indicate the potential for stronger sea breezes associated with climate change to cause summer daytime cooling while average seasonal temperatures continue to increase. These daytime cooling effects may have mitigated some effects of climate change on ozone air quality.

The objective of this research is to predict potential effects of future changes in climate, population, and emissions on ozone air quality in Southern California. Outcomes at different locations throughout the Los Angeles area are evaluated to assess interactions among the above factors.

\section{Methods}

The effects on ozone air quality of changes in five different factors (temperature, humidity, biogenic emissions, inflow boundary conditions, anthropogenic emissions) are evaluated in Southern California. Each of these factors is considered individually. In addition, the combined air quality effects of changes in temperature, biogenic emissions, and humidity represent an aggregate climate-related effect on air quality. The combined effects on air quality of future changes in anthropogenic emissions and inflow boundary conditions reflect effects of population growth and technology change, occurring locally in Southern California and globally. Each of these effects on air quality is evaluated relative to a base case high-ozone episode from summer 2005.

Air pollution formation and transport is modeled for a base case period of 14-19 July 2005, when observed ozone concentrations peaked at over $100 \mathrm{ppb}$ at many inland locations in Southern California. This time period has been used to support control strategy design in the 2007 Air Quality Management Plan for the Los Angeles area (SCAQMD, 2007). The model domain $(110 \times 74$ grid cells with $5 \mathrm{~km}$ horizontal resolution) is centered over downtown Los Angeles, extending west over the Pacific Ocean past the Channel Islands, and east over the Mojave Desert. The domain extends from northern Mexico to the south end of San Joaquin Valley as shown in Fig. 1. The vertical dimension is divided into 25 layers extending to $\sim 15 \mathrm{~km}$ above sea level, with a telescoping vertical grid starting at $36 \mathrm{~m}$ layer thickness at ground level and increasing to $6.5 \mathrm{~km}$ near the tropopause.

The Community Multiscale Air Quality model (CMAQ; Byun and Schere, 2006) version 4.6 is used to predict base case and future air quality. The SAPRC99 chemical mechanism (Carter, 2000), containing 77 model species (including lumped VOC categories) and 216 reactions, is used to describe relevant atmospheric chemistry. Boundary conditions similar to Steiner et al. (2006) were used here except that the $\mathrm{NO}$ and $\mathrm{NO}_{2}$ inflow (western) boundary conditions were reduced from $1 \mathrm{ppb}$ each to 0.01 and $0.03 \mathrm{ppb}$, respectively, based on Nowak et al. (2004). Meteorological fields were developed by the South Coast Air Quality Management District (SCAQMD, 2007) using the National Center for Atmospheric Research Mesoscale Meteorological model (MM5) version 3.6.1. Three two-way nested domains were used with spatial resolution of 45,15 , and $5 \mathrm{~km}$. Only the innermost $5 \mathrm{~km}$ meteorological fields were used in the present study to drive air quality model calculations. SCAQMD evaluated meteorological model predictions over the 14-19 July 2005 episode, in general finding small differences between modeled and observed temperature, wind speed, and humidity. For example, the daily average bias in wind speed ranged from -0.03 to $0.23 \mathrm{~m} / \mathrm{s}$. For temperature, most days had smaller than a $-0.5^{\circ} \mathrm{C}$ bias compared to observation, the largest temperature bias was for 19 July $-1.2^{\circ} \mathrm{C}$. The largest bias of humidity was $-5 \%$, also for 19 July. 


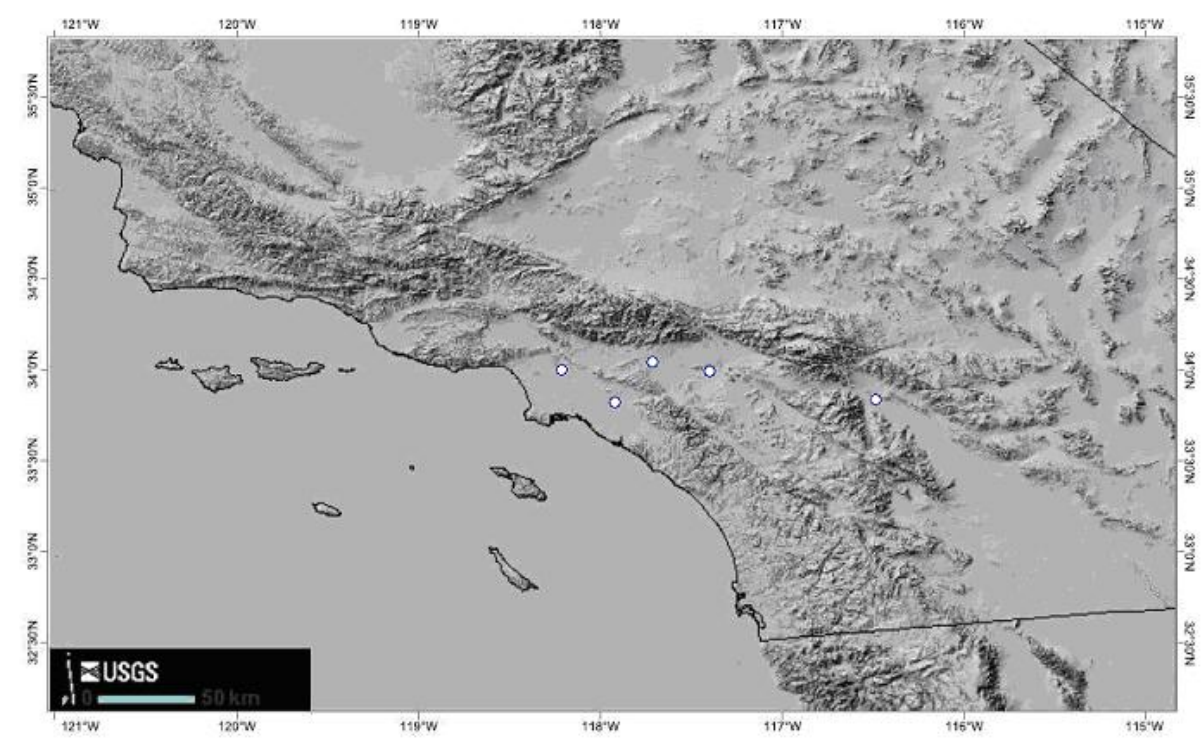

Fig. 1. Map of Southern California study domain used for air quality modeling in the present study. Locations highlighted from left to right: Central Los Angeles, Anaheim, Pomona, Riverside, and Palm Springs.
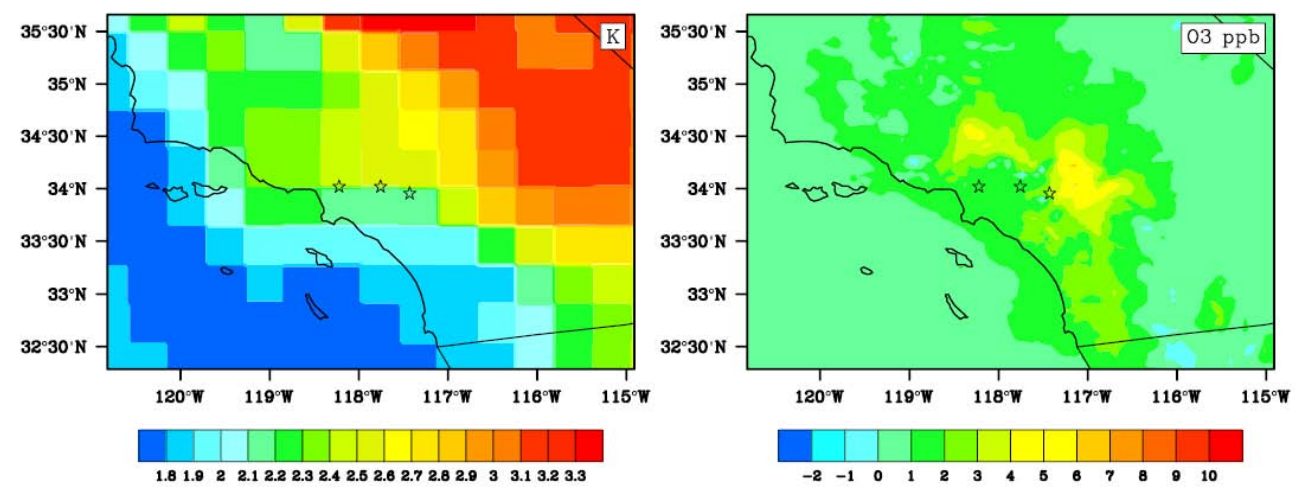

Fig. 2. Difference between future and base case temperatures, and resulting changes in weekday-average ozone concentrations at 15:00 h LT. The locations shown are from left to right, Central Los Angeles, Pomona/Claremont, and Riverside.

The base case emission inventory used here was provided by the California Air Resources Board (Jackson, 2007). Separate hourly and day-specific gridded estimates of mobile, point, and area source emissions were combined with biogenic emission estimates developed using the BEIGIS model (Scott and Benjamin, 2003). Table 1 shows domain-wide emission totals for $\mathrm{NO}_{\mathrm{x}}$, non-methane organic compounds (NMOC), and CO, for each category of emissions. Table 1 highlights the importance of both on-road mobile emissions as well as off-road/area emission as important sources. A high degree of emission control has been achieved on large point sources such as power plants in Southern California, so these sources are of relatively minor importance here.

Perturbations to the base case air quality model were developed and applied using results from a global and regional climate modeling study by Snyder et al. (2002). A dou- bling of pre-industrial global background $\mathrm{CO}_{2}$ levels from 280 to $560 \mathrm{ppm}$ was the basis for future climate calculations. The domain used in the regional climate model was centered on California with a horizontal resolution of $40 \mathrm{~km}$. This fine resolution is needed to capture the wide variety of elevations, land cover types, and microclimates that are found within California. The regional climate model was forced using global-scale predictions from the NCAR parallel climate model for the $2 \times \mathrm{CO}_{2}$ scenario. See Snyder et al. (2002) for further details. Predicted temperature increases in Southern California for July range from 1.6 to $3.5^{\circ} \mathrm{C}$, with larger increases predicted to occur further inland, as shown in the first panel of Fig. 2. Temperature changes from Snyder et al. (2002) are monthly average values based on 5-year long regional scenarios and are applied evenly across all times of day and week except when otherwise specified. 
Table 2. AVOC, BVOC and $\mathrm{NO}_{\mathrm{x}}$, base case and future emissions by county. Emissions are reported in tons/day for Thursday 14 July.

\begin{tabular}{lrrrrrrrrrr}
\hline County & $\begin{array}{r}\text { Pop. } \\
\text { Growth }\end{array}$ & $\begin{array}{r}\text { Base } \\
\text { Case } \\
\mathrm{NO}_{\mathrm{x}}\end{array}$ & $\begin{array}{r}\text { Future } \\
\mathrm{NO}_{\mathrm{x}}\end{array}$ & $\begin{array}{r}\% \\
\text { chg }\end{array}$ & $\begin{array}{r}\text { Base } \\
\text { Case } \\
\text { AVOC }\end{array}$ & $\begin{array}{r}\text { Future } \\
\text { AVOC }\end{array}$ & $\begin{array}{r}\% \text { chg } \\
\text { Base } \\
\text { Case } \\
\text { BVOC }^{1}\end{array}$ & $\begin{array}{r}\text { Future } \\
\text { BVOC }^{1}\end{array}$ & $\begin{array}{r}\% \\
\text { chg }\end{array}$ \\
\hline Imperial & 2.3 & 34.8 & 32.4 & $-7 \%$ & 53.1 & 24.7 & $-53 \%$ & 6.3 & 7.8 & $+25 \%$ \\
Kern & 2.7 & 181.5 & 198.9 & +10 & 90.4 & 49.6 & -45 & 52.0 & 59.1 & +14 \\
Orange & 1.3 & 524.8 & 272.9 & -48 & 377.8 & 98.2 & -74 & 34.4 & 35.6 & +3 \\
Riverside & 1.3 & 143.8 & 75.4 & -48 & 136.2 & 35.7 & -74 & 7.5 & 6.8 & -9 \\
San Bernardino & 2.5 & 145.6 & 145.0 & -0.4 & 107.9 & 53.7 & -50 & 25.4 & 30.3 & +19 \\
San Diego & 1.9 & 210.3 & 158.1 & -25 & 110.5 & 41.5 & -62 & 20.6 & 27.6 & +34 \\
San Louis Obispo & 1.5 & 162.5 & 96.9 & -40 & 163.7 & 48.8 & -70 & 53.1 & 55.3 & +4 \\
Santa Barbara & 1.4 & 20.9 & 11.8 & -44 & 21.1 & 6.0 & -72 & 26.5 & 25.3 & -4 \\
Ventura & 1.3 & 34.1 & 17.4 & -49 & 37.1 & 9.5 & -74 & 43.6 & 40.9 & -6 \\
Non-County & 1.5 & 53.4 & 32.5 & -39 & 46.2 & 14.1 & -70 & 27.0 & 29.4 & +9 \\
Total & 1.6 & 115.6 & 74.9 & -35 & 37.5 & 12.2 & -68 & 0.2 & 0.2 & -6 \\
\hline
\end{tabular}

${ }^{1}$ Reported in this column are biogenic emissions of terpenes, isoprene, and methyl-butenol. Future emissions of these compounds were changed based on future temperature predictions.

Perturbations to the base case were considered separately to isolate the effects of individual variables. Temperature changes affect chemical reaction rates in the model, but these changes were not linked to other variables such as wind speed or planetary boundary layer height, which remained the same as in the base case. Temperature changes were mapped directly from the regional climate model to the air quality domain. Both climate and mesoscale meteorological models used a Lambert conformal map projection which facilitated superposition of regional climate model-derived temperature perturbations on the MM5-derived meteorological fields.

The effect of increased temperatures on biogenic emissions of volatile organic compounds was modeled as a separate effect. Biogenic emissions of isoprene and methylbutenol are sensitive to temperature and light, whereas terpenes are sensitive to temperature but not light. For the future temperature scenario, emissions of isoprene and terpenes were scaled using algorithms described by Guenther et al. (1993). Methyl-butenol emissions were adjusted following Harley et al. (1998). These algorithms show all emissions increasing exponentially with temperature increases, but note isoprene and methyl-butenol emissions saturate at temperatures above $40^{\circ} \mathrm{C}$. In this scenario, biogenic emissions were calculated for the higher temperature regime while atmospheric chemistry proceeded at temperature-dependent rates equal to those of the base case. This isolated the effects of biogenic emission changes on air quality.
Assuming relative humidity remains constant in the future climate scenario, absolute humidity was adjusted given the new (higher) temperatures. This calculation adjusts the ratio of ( $\mathrm{g}$ water)/(kg air) to maintain the same relative humidity under future temperature conditions. Note that in the "humidity only" scenario relative and absolute humidity both increase, while temperature is held constant. For the combined climate case, relative humidity is unchanged between future and base case scenarios, as both absolute humidity and temperature increase.

Future anthropogenic emissions were estimated from current emissions, scaled to account for population growth and technology change. Population growth in California through 2050 has been forecast at the county level (DOF, 2007). We assumed that improved technologies and increased regulation of air pollution sources will reduce $\mathrm{VOC}, \mathrm{CO}$, and $\mathrm{NO}_{\mathrm{x}}$ emission factors by $80 \%$ below present-day (circa 2000, already controlled) levels. Following Steiner et al. (2006), growth in $\mathrm{NO}_{\mathrm{x}}$ emissions is estimated as double VOC growth because of expected continuing increases in the freighttransport sector. Table 2 shows anthropogenic and biogenic VOC and $\mathrm{NO}_{\mathrm{x}}$ emission totals by county for Thursday, 14 July, for future conditions and base case conditions. Included are the growth factors for each county. Future domain-wide $\mathrm{NO}_{\mathrm{x}}$ emissions decrease from the base case by $31 \%$ while anthropogenic VOC emissions decrease by roughly double this amount. This future emission scenario is based on past trends in California and does not reflect current greenhouse 

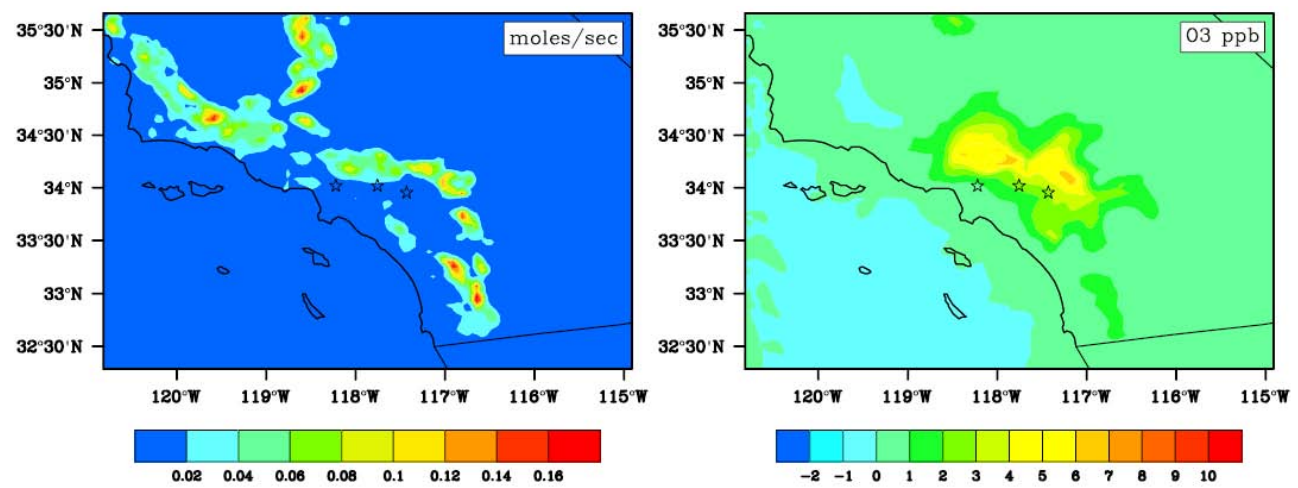

Fig. 3. Difference between future and base case biogenic emissions, and resulting changes in weekday-average ozone concentrations at 15:00 h LT. The locations shown are from left to right, Central Los Angeles, Pomona/Claremont, and Riverside.

gas regulatory efforts that may also influence the trajectory of $\mathrm{NO}_{\mathrm{x}}$ and VOC emission reductions.

Future inflow boundary conditions were adjusted following Steiner et al. (2006), using increased concentrations of $\mathrm{CO}$, ozone, and methane in response to emission increases in the A1B scenario between 2000 and 2050 (IPCC, 2001). In order to highlight the potential effects from increasing emissions in Asia, ozone concentrations were increased by roughly double the amount predicted in the A1B scenario, a scenario that predicts economic growth with market based approaches to limiting greenhouse gas emissions and assumes no single energy generation technology is dominant. Parrish et al. (2004; 2009), and Jaffe et al. (2003) describe observed increases in ozone levels in Pacific Ocean inflow to the western United States, raising concerns about disproportionately higher impacts for ozone. Therefore in this study at the western inflow boundary, CO was increased by $30 \%$, methane was increased by $40 \%$, and ozone was increased by $30 \%$.

\section{Results and discussion}

\subsection{Base case model evaluation}

Ozone predictions were compared to observations at 83 surface sites. Comparing all ozone observations above $40 \mathrm{ppb}$ with model predictions, a normalized bias of $+3 \%$ and a normalized error of $30 \%$ were found. The spatial distribution of ozone in the model matches that seen in the observations, with the best agreement found in the urbanized areas around Los Angeles. A comparison of model output to observations at five representative locations is presented in Supplemental Fig. 1 http://www.atmos-chem-phys.net/9/3745/ 2009/acp-9-3745-2009-supplement.pdf. The modeling domain is well-suited to studying photochemical air pollution in the South Coast air basin. In contrast, both San Diego and the southern San Joaquin Valley lie at the edges of the study area used here and as such are subject to larger uncertainties due to their proximity to northern and southern boundaries of the modeling domain.

\subsection{Effects of climate change}

A series of model runs was conducted to determine the sensitivity of air quality in Southern California to future changes in emissions and climate. Figures 2, 3, and 4 show differences in input data and resulting changes in ozone air quality between various modeled perturbations and the summer 2005 base case. The spatial patterns of ozone changes are shown at 03:00 p.m., which is a high-ozone time of day. Time series plots showing ozone changes at all times of day are presented in supplemental information and discussed later.

The effect of increased temperatures on chemical reaction rates is to increase peak ozone levels across the domain. Figure 2 shows the change in temperature and corresponding peak ozone response. Inland areas that experience larger future temperature increases and are close enough to Los Angeles to be strongly influenced by its emissions showed the strongest ozone response to temperature changes.

Figure 3 shows changes in biogenic emissions and the corresponding peak ozone response. Similar to the results shown in Fig. 2, Fig. 3 shows little change in ozone for the coastal areas of Orange and Los Angeles Counties and larger ozone increases further inland. The effects of biogenic emission increases are mitigated to some extent by the spatial distribution of these emissions, which occur mostly in the surrounding mountains rather than within urbanized areas. Increased biogenic emissions had the largest effects on ozone in areas north and east of Los Angeles. Over much of the domain, biogenic emissions increased by $20-35 \%$ compared to the base case as a result of higher temperatures.

The response of peak ozone to increased humidity is positive in most urbanized areas, and can be seen in Supplemental Fig. 2 (http://www.atmos-chem-phys.net/9/3745/ 

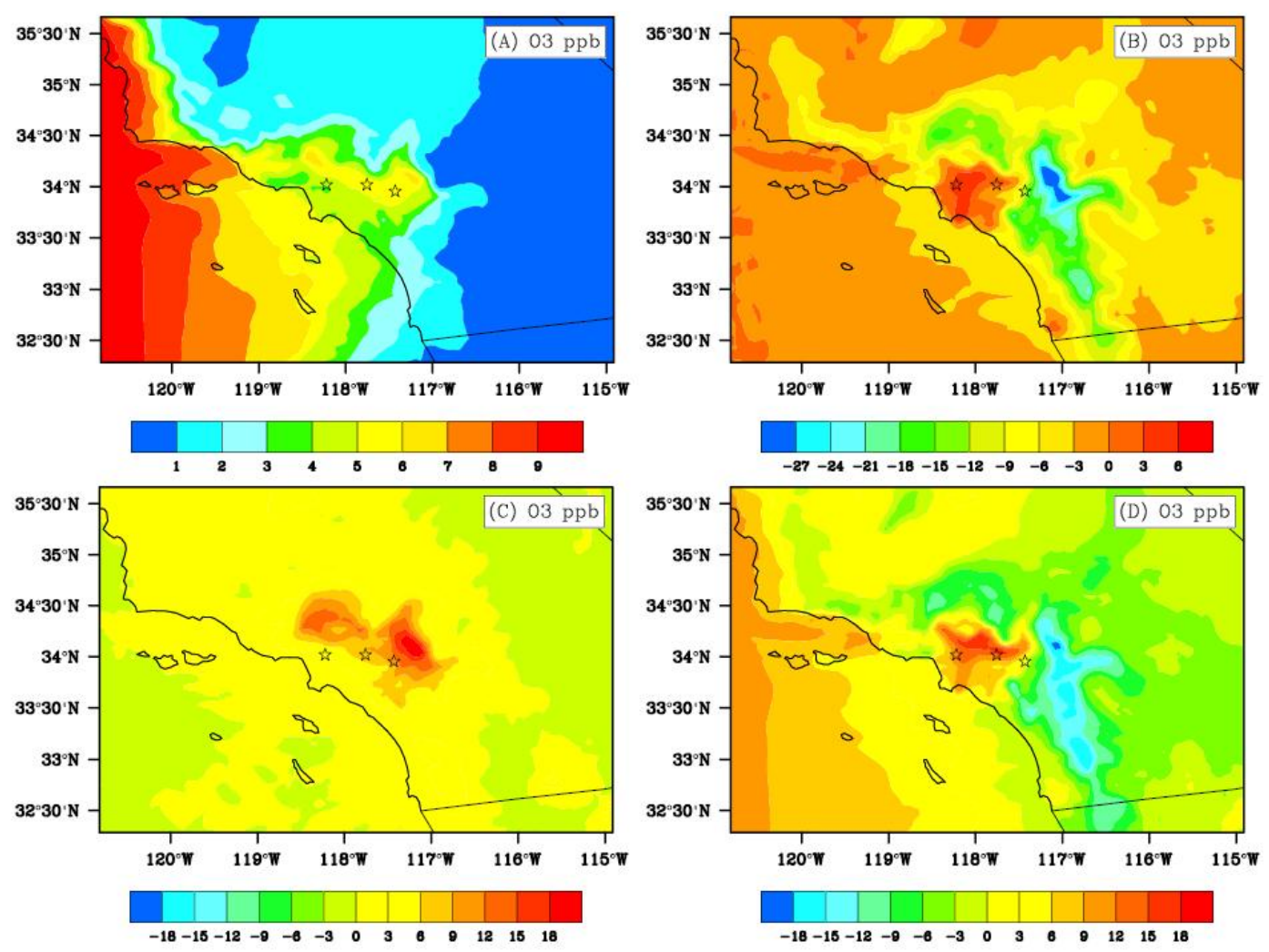

Fig. 4. Differences between future and base case $\mathrm{O}_{3}$ concentrations on weekdays at 15:00 h LT. The locations shown are from left to right, Central Los Angeles, Pomona/Claremont, and Riverside. (a) Future inflow boundary condition scenario, (b) Future anthropogenic emissions, (c) Future climate perturbations (increased temperature, absolute humidity, biogenic emissions), (d) all perturbations (a-c) combined together.

Table 3. Average weekday ozone (ppb) at 15:00 h LT (local time): base case levels and differences between specified run and base case.

\begin{tabular}{lrrrrr}
\hline & Anaheim & Central L.A. & Pomona & Riverside & Palm Springs \\
Base case $\mathrm{O}_{3}$ & 44.6 & 39.9 & 51.2 & 82.3 & 91.5 \\
\hline 1) Temperature & +1.3 & +1.6 & +1.5 & +3.3 & +2.2 \\
2) Biogenic VOC & +0.6 & +1.0 & +2.8 & +2.9 & +0.9 \\
3) Humidity & +0.1 & +0.9 & +3.4 & +4.4 & -1.1 \\
4) 2050 Emissions & +1.4 & +4.3 & +2.5 & -13.5 & -7.9 \\
5) Inflow BC & +4.3 & +4.3 & +5.5 & +5.4 & +1.0 \\
6) Combined 1-3 & +2.2 & +3.5 & +8.5 & +11.3 & +2.1 \\
7) Combined 4-5 & +6.1 & +8.8 & +8.3 & -8.2 & -6.9 \\
8) Combined 1-5 & +7.9 & +11.2 & +16.0 & -0.3 & -5.6 \\
\hline
\end{tabular}

2009/acp-9-3745-2009-supplement.pdf). The increase in water vapor leads to greater production of $\mathrm{HO}_{\mathrm{x}}$ as a result of ozone photolysis, and thus increased atmospheric processing of pollutants such as $\mathrm{NO}_{\mathrm{x}}$ and VOC. For example, in response to humidity changes, modeled afternoon $\mathrm{NO}_{\mathrm{x}}$ concentrations in and around Pomona and Riverside decrease by an average of 3 and $6 \%$, respectively. In these $\mathrm{NO}_{\mathrm{x}}$ saturated regions, modeled ozone levels increase as a result. Further 
east, a smaller $\mathrm{NO}_{\mathrm{x}}$ decrease is seen, for example $2 \%$ at Palm Springs, but this area is more remote and $\mathrm{NO}_{\mathrm{x}}$ limited thus ozone concentrations decrease in response.

\subsection{Effects of emission and inflow boundary condition changes}

Increased pollutant concentrations at the western inflow boundary increase peak ozone levels consistently across all sites except Palm Springs (see Fig. 4a). There are large relative increases in ozone near the coast where base case ozone levels were generally lower compared to inland locations.

Under the future emission scenario, emissions of $\mathrm{NO}_{\mathrm{x}}$, VOC and CO decrease across the domain. Coastal areas see reductions of $35-50 \%$ in $\mathrm{NO}_{\mathrm{x}}$ emissions and even larger reductions in VOC. The resulting effects on ozone were mixed, due to spatial differences in ozone sensitivity to VOC versus $\mathrm{NO}_{\mathrm{x}}$ emissions as well as differences in predicted growth rates between the counties. In central Los Angeles future emissions and inflow create an increase in peak ozone levels of up to $9 \mathrm{ppb}$, whereas Riverside sees a similar sized decrease. The effects of future changes in inflow BC and local emissions taken together are shown in Fig. $4 \mathrm{~b}$ (combined anthropogenic effects scenario).

\subsection{Combined effects}

Figure $4 c$ shows the ozone air quality impact of a combined climate forcing case, incorporating changes to temperatures, absolute humidity, and biogenic emissions. Increases in peak ozone are seen across the domain, ranging from 3-15 ppb, with the largest increases occurring inland near Riverside. The combined anthropogenic effects and climate change scenario shows increases in peak ozone at most locations with decreases seen only far inland (Fig. 4d).

Table 3 summarizes changes in peak 1-h ozone between each future scenario and the base case. Combined scenarios 6-8 are not linear combinations of individual scenarios 1-5, but instead represent results of additional model runs incorporating various combinations of the individual perturbations as noted in Table 3. Supplemental Table 1 (http://www.atmos-chem-phys.net/9/3745/2009/ acp-9-3745-2009-supplement.pdf) shows changes in peak 8$\mathrm{h}$ ozone for each scenario, with results that follow closely those of the 1-h ozone changes in Table 3.

The locations shown in Table 3 were chosen to span future air quality outcomes in populated areas near Los Angeles. Figure 1 shows a map of the study area including the locations of these 5 sites. Anaheim is located in Orange County, south of Los Angeles. The Central Los Angeles site is located near downtown, approximately $20 \mathrm{~km}$ from the coast. Pomona, Riverside, and Palm Springs are located progressively further east of Los Angeles. Pomona is $\sim 40 \mathrm{~km}$ east of Los Angeles and Riverside is $\sim 40 \mathrm{~km}$ east of Pomona. Although the terrain becomes more complex traveling east from Los Angeles to Riverside, no major mountains are located between these locations. Palm Springs and the Mojave Desert are separated from Riverside by mountain ranges.

Overall there are large changes in peak ozone due to changes in both climate and emissions. Ozone increases across the greater Los Angeles area, and decreases east of Riverside. The changes in peak ozone range over $\pm 17.5 \mathrm{ppb}$. More detailed forecasts of future emissions are needed, and air quality management plans may need to be adjusted to account for ozone increases that may occur due to climate change.

A sensitivity analysis of the combined future emissions and climate scenario shows that urban areas from downtown Los Angeles east to Riverside remain $\mathrm{NO}_{\mathrm{x}}$ saturated (see Supplemental Fig. 3 http://www.atmos-chem-phys.net/ 9/3745/2009/acp-9-3745-2009-supplement.pdf). This may seem counter-intuitive as the isolated future emissions scenario showed ozone decreases in the Riverside area. However, high growth is predicted in Riverside, canceling out predicted improvements in emissions control in this scenario. Thus the isolated future emission scenario shows reduced ozone in Riverside occurring because of emission reductions elsewhere while maintaining steady emissions locally. The sensitivity analysis measures the ozone response to a uniform percentage change across the domain. The sensitivity response indicates that future $\mathrm{NO}_{\mathrm{x}}$ control would need to be much stronger than estimated in this work in order to shift populated regions from $\mathrm{NO}_{\mathrm{x}}$ saturated to $\mathrm{NO}_{\mathrm{x}}$ limited regimes. Secondly, since urban areas from Los Angeles to Riverside remain $\mathrm{NO}_{\mathrm{x}}$ saturated, ozone response to emission and climate changes in between the modeled year 2050 and present can be expected to maintain the same sign as and fall below changes predicted by the combined emission and climate scenario.

\subsection{Temporal patterns of ozone change}

Riverside lies near the interface between positive and negative ozone outcomes under the combined scenario of future climate, emissions, and inflow boundary conditions. The magnitude and even the sign of the change in ozone concentrations at Riverside are timedependent. The ozone response differs both by time of day, and for weekdays versus the weekend. Supplemental Fig. 4 (http://www.atmos-chem-phys.net/9/3745/2009/ acp-9-3745-2009-supplement.pdf) shows predicted difference between base case and future scenario ozone concentrations by time of day at five locations.

Future ozone is closest to base case predictions around noon, although the sign of the change varies from day to day at Riverside. At other sites, such as Pomona and central Los Angeles, future ozone concentrations are consistently higher than in the base case. This is due to a combination of air quality penalties due to climate change and higher inflow boundary conditions, and a local effect of 

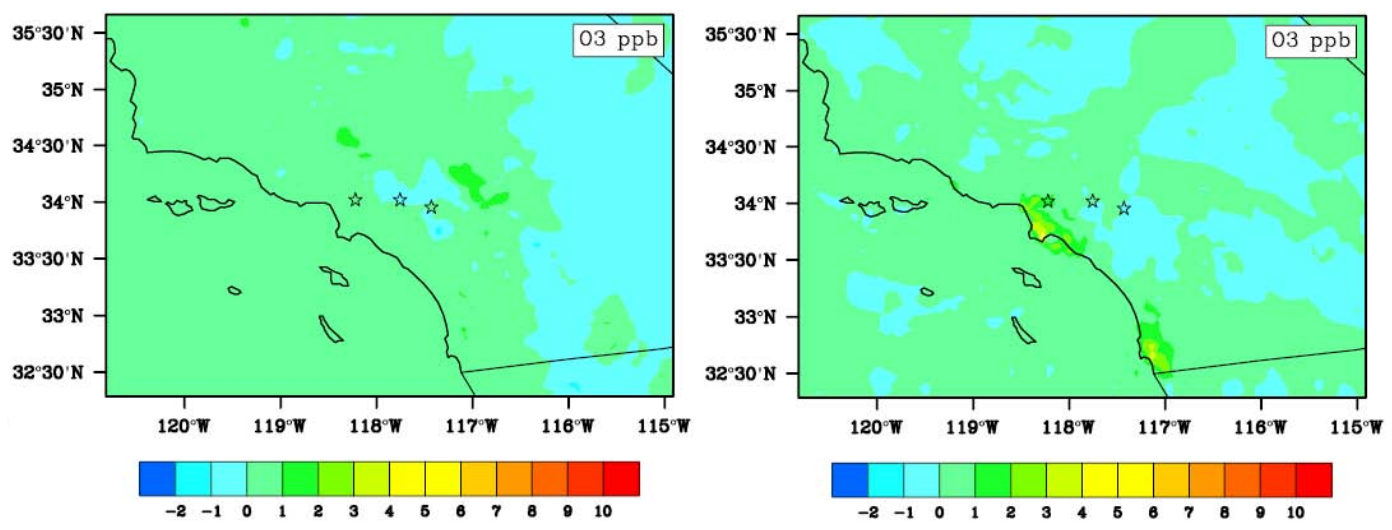

Fig. 5. Difference between future and base case ozone concentrations on weekdays at 03:00 h LT (left panels) and 15:00 h LT (right panels). Compare right panel here vs. Fig. 2 where T increase was applied uniformly throughout the day instead of mostly at night. The locations shown are from left to right, Central Los Angeles, Pomona/Claremont, and Riverside.

lower $\mathrm{NO}_{\mathrm{x}}$ emissions on ozone in upwind areas, where the system is $\mathrm{NO}_{\mathrm{x}}$-saturated. Added model uncertainty exists for nighttime conditions when the observed partitioning of odd oxygen between $\mathrm{NO}_{2}$ and $\mathrm{O}_{3}$ in the nocturnal boundary layer is difficult to reproduce.

\subsection{Future temperature change}

Temperature perturbations applied here so far do not consider possible time-of-day dependence. Historically (i.e., from 1950 to present day) however, observed temperature increases during summer months have been largest at nighttime hours in many areas of California, and little increase in daytime maximum temperatures has been reported in the observed record (Bonfils et al., 2008). To evaluate the effect of a diurnally-varying rather than uniform temperature increase on atmospheric chemistry and biogenic VOC emissions, an alternate form of the temperature perturbation was developed. Future temperatures were recalculated as a function of time of day:

$T(t)=T_{0}(t)+\Delta T\left[1+0.8 \cos \left(\frac{2 \pi t}{24}\right)\right]$

Where $T_{0}$ is the original temperature in the base case scenario, $t$ is time in hours past midnight, and $\Delta T$ is the 24$\mathrm{h}$ average increase in temperature predicted by Snyder et al. (2002) for the month of the July. The amplitude of the oscillatory component $(0.8)$ is arbitrary, but was chosen so that most but not all of the temperature increase occurs at night. Applying the past record of summer daytime cooling due to increased irrigation of 0.14 to $0.25^{\circ} \mathrm{C}$ per decade in California (Bonfils and Lobell, 2007) to the 2050 temperature predictions by Snyder et al. (2002) removes most but not all of the daytime temperature increases and is consistent with Eq. (1).
The increase in peak ozone predicted above with a uniform temperature increase mostly disappears when the temperature increase occurs predominantly at night. Figure 5 shows the effects on ozone of increased temperature using a diurnally-varying temperature change (Eq. 1) relative to the base case at 03:00 and 15:00 h LT on weekdays. More generally, ozone concentrations show little change at any time of day relative to the base case when temperature increases occur mostly at nighttime hours (see Supplemental Fig. 5 http://www.atmos-chem-phys.net/9/3745/ 2009/acp-9-3745-2009-supplement.pdf).

Similar results were found when biogenic emissions were recalculated using diurnally- varying temperature changes. Emissions of isoprene and methyl-butenol are both temperature and light-sensitive, and emissions of these compounds are zero at night. Nighttime temperature increases do increase terpene emissions, but the absolute effect of temperature increases on terpene emissions is reduced because baseline temperatures are lower at night. Ozone concentrations do not increase nearly as much as when temperatures were increased uniformly throughout the day. Changes in ozone at 03:00 and 15:00 h LT due to revised estimates of biogenic VOC emission increases are shown in Supplemental Fig. 6 (http://www.atmos-chem-phys.net/9/3745/ 2009/acp-9-3745-2009-supplement.pdf).

The diurnal pattern of future temperature changes is important to assessments of climate change impacts on ozone air quality. Nighttime temperature increases have less effect on ozone production than similar temperature increases that occur at midday. However, the historical record of temperature increases is not necessarily a good predictor of future warming. Irrigation, which increased over the last century in California, is unlikely to continue to increase in the same manner in future years. Loss of agricultural lands to urbanization and scarcity of water may slow or reverse the 
expansion in irrigated lands. In fact the amount of irrigated land in California has remained relatively stable since the 1980s (Bonfils and Lobell, 2007). Thus, any past mitigating effect of increased irrigation on daytime warming is unlikely to be repeated over the next 50 years.

Other mechanisms for a diurnal pattern of future temperature change have been proposed by Lebassi et al. (2009), who observed an increase in on-shore sea breezes that may have mitigated summer daytime warming relative to surrounding areas that are sheltered from these breezes. Both changes to irrigation and to sea breeze patterns have the potential to affect humidity levels as well as future diurnal temperature changes. Further research is needed to understand these effects and their interactions with air quality.

\section{Summary and recommendations}

This study investigated ozone air quality effects of future climate change, inflow pollutant boundary conditions, and anthropogenic emissions on ozone air quality in Southern California. Future temperature changes were predicted at high spatial resolution in California for a scenario of $2 \times$ preindustrial $\mathrm{CO}_{2}$ levels. Future emissions were predicted starting from a baseline emission inventory, factoring in expected population growth and likely advances in emission control technologies.

Globally-driven climate changes led to ozone increases throughout the study domain. In this study, climate change affected ozone levels through three mechanisms: increased temperature, increased humidity, and increased biogenic VOC emissions. These effects contribute to a climate change penalty for air quality management: additional controls on anthropogenic emissions will be needed to offset undesired effects of climate change on ozone. Likewise, future increases in pollutants, especially ozone, entering southern Calfornia via inflow from the Pacific Ocean will lead to increased mainland ozone levels, with coastal areas being especially vulnerable to this effect. The response of ozone air quality to future emission changes varied by location, with ozone increases predicted in upwind areas, and ozone decreases further downwind.

Recent commitments to control greenhouse gas emissions in California may also affect criteria pollutant emissions, and this issue requires further study. As noted above, the diurnal pattern of temperature change is important in assessing climate change effects on ozone air quality. More detailed information is needed on anticipated temperature changes as a function of time of day.

While this work focuses on how climate and future emissions influence the severity of a particular ozone episode, other investigations study factors that influence the frequency of these events. For example, Leung and Gustafson (2005) consider effects such as changes in the number of stagnation events and the length of the high-ozone season. Other issues to consider include climate change effects on fine particulate matter levels, (Kleeman, 2008), and changes to other meteorological variables, such as precipitation, wind patterns, mixing and cloud cover. Finally, changes in forest fires may be an important aspect of the response to changing climate (Brown et al., 2004), with potentially serious effects on air quality.

Acknowledgements. We gratefully acknowledge the California Air Resources Board for providing financial and technical support for this study. We also acknowledge the US Environmental Protection Agency for support of earlier work that led to this study. The statements and conclusions herein are those of the authors and do not necessarily reflect the views of the project sponsor. We thank Philip Duffy, Bruce Jackson, Michael Kleeman, Nehzat Motallebi, and Mark Snyder for their assistance.

Edited by: J. Seinfeld

\section{References}

Aw, J. and Kleeman, M. J.: Evaluating the first-order effect of intraannual temperature variability on urban air pollution, J. Geophys. Res., 108, 4365, doi:10.1029/2002JD002688, 2003.

Bonfils, C. and Lobell, D.: Empirical evidence for a recent slowdown in irrigation-induced cooling, P. Natl. Acad. Sci. USA, 104, 13582-13587, 2007.

Bonfils, C., Duffy, P. B., Santer, B. D., Wigley, T. M. L., Lobell, D. B., Phillips, T. J., and Doutriaux, C.: Identification of external influences on temperatures in California, Climatic Change, 87, S43-S55, 2008.

Brasseur, G. P., Schultz, M., Granier, C., Saunois, M., Diehl, T., Botzet, M., Roeckner, E., and Walters, S.: Impact of climate change on the future chemical composition of the global troposphere, J. Climate, 19, 3932-3951, 2006.

Brown, T. J., Hall, B. L., and Westerling, A. L.: The impact of twenty-first century climate change on wildland fire danger in the western United States: An applications perspective, Climatic Change, 62, 365-388, 2004.

Byun, D. and Schere, K. L.: Review of the governing equations, computational algorithms, and other components of the models3 Community Multiscale Air Quality (CMAQ) modeling system, Appl. Mech. Rev., 59, 51-77, 2006.

Carter, W. P. L.: Implementation of the SAPRC-99 Chemical Mechanism into the Models-3 Framework, College of Engineering, University of California, Riverside, CA, Report to the United States Environmental Protection Agency, 3-23, 56-60, 2000.

Clark, T. L. and Karl, T. R.: Application of Prognostic Meteorological Variables to Forecasts of Daily Maximum One-Hour Ozone Concentrations in the Northeastern United-States, J. Appl. Meteorol., 21, 1662-1671, 1982.

DOF: Population Projections for California and Its Counties 20002050, California Deptartment of Finance, Sacramento, CA, July 2007.

Duffy, P. B., Bonfils, C., and Lobell, D.: Interpreting Recent Temperature Trends in California, EOS, Transactions, American Geophysical Union, 88, 409-424, 2006.

Guenther, A. B., Zimmerman, P. R., Harley, P. C., Monson, R. K., and Fall, R.: Isoprene and Monoterpene Emission Rate 
Variability - Model Evaluations and Sensitivity Analyses, J. Geophys. Res., 98 (D7), 12609-12617, 1993.

Harley, P., Fridd-Stroud, V., Greenberg, J., Guenther, A., and Vasconcellos, P.: Emission of 2-methyl-3-buten-2-ol by pines: A potentially large natural source of reactive carbon to the atmosphere, J. Geophys. Res., 103(D19), 25479-25486, 1998.

IPCC: Intergovernmental Panel on Climate Change. Climate Change 2001: The Scientific Basis, edited by: Houghton, J. T., Ding, Y., Griggs, D. J., Noguer, M., Van Der Linden, P. J., Dai, X., Maskell, K., and Johnson, C. A., Cambridge University Press, Cambridge, UK and New York, NY, USA, 63, 800-810, 2001.

Jackson, B.: Planning and Technical Support Division, California Air Resources Board, Sacramento, CA, personal communication, December 2007.

Jacobson, M. Z.: On the causal link between carbon dioxide and air pollution mortality, Geophys. Res. Lett., 35, L03809, doi:10.1029/2007GL031101, 2008.

Jaffe, D., Price, H., Parrish, D., Goldstein, A., and Harris, J.: Increasing background ozone during spring on the west coast of North America, Geophys. Res. Lett., 30, doi:10.1029/2003GL017024, 2003.

Kleeman, M. J.: A preliminary assessment of the sensitivity of air quality in California to global change, Climatic Change, 87, S273-S292, 2008.

Lebassi, B., González, J., Fabris, D., Maurer, E., Miller, N., Milesi, C., Switzer, P., and Bornstein, R.: Observed 1970-2005 Cooling of Summer Daytime Temperatures in Coastal California, J. Climate, doi:10.1175/2008JCLI2111.1, in press, 2009.

Leung, L. R. and Gustafson, W. I.: Potential regional climate change and implications to US air quality, Geophys. Res. Lett., 32, L16711, doi:10.1029/2005GL022911, 2005.

Liao, H., Chen, W. T., and Seinfeld, J. H.: Role of climate change in global predictions of future tropospheric ozone and aerosols, J. Geophys. Res., 111, D12304, doi:10.1029/2005JD006852, 2006.

Lin, C. Y. C., Jacob, D. J., and Fiore, A. M.: Trends in exceedances of the ozone air quality standard in the continental United States, 1980-1998, Atmos. Environ., 35, 3217-3228, 2001.

Lobell, D. B. and Bonfils, C.: The effect of irrigation on regional temperatures: A spatial and temporal analysis of trends in California, 1934-2002, J. Climate, 21, 2063-2071, 2008.

Mickley, L. J., Jacob, D. J., Field, B. D., and Rind, D.: Effects of future climate change on regional air pollution episodes in the United States, Geophys. Res. Lett., 31, L24103, doi: 10.1029/2004GL021216, 2004.

Nowak, J. B., Parrish, D. D., Neuman, J. A., Holloway, J. S., Cooper, O. R., Ryerson, T. B., Nicks, D. K., Flocke, F., Roberts, J. M., Atlas, E., de Gouw, J. A., Donnelly, S., Dunlea, E., Hubler, G., Huey, L. G., Schauffler, S., Tanner, D. J., Warneke, C., and Fehsenfeld, F. C.: Gas-phase chemical characteristics of Asian emission plumes observed during ITCT 2K2 over the eastern North Pacific Ocean, J. Geophys. Res., 109, D23S19, doi:10.1029/2003JD004488, 2004.
Parrish, D. D., Dunlea, E. J., Atlas, E. L., Schauffler, S., Donnelly, S., Stroud, V., Goldstein, A. H., Millet, D. B., McKay, M., Jaffe, D. A., Price, H. U., Hess, P. G., Flocke, F., and Roberts, J. M.: Changes in the photochemical environment of the temperate North Pacific troposphere in response to increased Asian emissions, J. Geophys. Res., 109, D23S18, doi:10.1029/2004JD004978, 2004.

Parrish, D. D., Millet, D. B., and Goldstein, A. H.: Increasing ozone in marine boundary layer inflow at the west coasts of North America and Europe, Atmos. Chem. Phys., 9, 1303-1323, 2009, http://www.atmos-chem-phys.net/9/1303/2009/.

Racherla, P. N. and Adams, P. J.: Sensitivity of global tropospheric ozone and fine particulate matter concentrations to climate change, J. Geophys. Res., 111, D24103, doi:10.1029/2005JD006939, 2006.

Racherla, P. N. and Adams, P. J.: The response of surface ozone to climate change over the Eastern United States, Atmos. Chem. Phys., 8, 871-885, 2008, http://www.atmos-chem-phys.net/8/871/2008/.

SCAQMD: Air Quality Management Plan, Appendix 5, Modeling and Attainment Demonstrations, Southern California Air Quality Management District, Diamond Bar, CA, June, V-1-11, V-2-18, V-4-23 to V-4-29, 2007.

Scott, K. I. and Benjamin, M. T.: Development of a biogenic volatile organic compounds emission inventory for the SCOS97NARSTO domain, Atmos. Environ., 37, S39-S49, 2003.

Sillman, S. and Samson, F. J.: Impact of Temperature on Oxidant Photochemistry in Urban, Polluted Rural and Remote Environments, J. Geophys. Res., 100, 11497-11508, 1995.

Snyder, M. A., Bell, J. L., Sloan, L. C., Duffy, P. B., and Govindasamy, B.: Climate responses to a doubling of atmospheric carbon dioxide for a climatically vulnerable region, Geophys. Res. Lett., 29, 11, doi:10.1029/2001GL014431, 2002.

Steiner, A. L., Tonse, S., Cohen, R. C., Goldstein, A. H., and Harley, R. A.: Influence of future climate and emissions on regional air quality in California, J. Geophys. Res., 111, D18303, doi:10.1029/2005JD006935, 2006.

Stevenson, D., Doherty, R., Sanderson, M., Johnson, C., Collins, B., and Derwent, D.: Impacts of climate change and variability on tropospheric ozone and its precursors, Faraday Discuss., 130, 1-17, doi:10.1039/b417412g, 2005.

Unger, N., Shindell, D. T., Koch, D. M., Amann, M., Cofala, J., and Streets, D. G.: Influences of man-made emissions and climate changes on tropospheric ozone, methane, and sulfate at 2030 from a broad range of possible futures, J. Geophys. Res., 111, D12313, doi:10.1029/2005JD006518, 2006. 